\title{
Tissue-specific effects of benzo[a]pyrene and DDT on microRNA expression profile in female rats
}

\author{
${ }^{1}$ Institute of Molecular Biology and Biophysics, Novosibirsk, Russia \\ ${ }^{2}$ Novosibirsk State Pedagogical University, Novosibirsk, Russia \\ ${ }^{3}$ Novosibirsk State University, Novosibirsk, Russia \\ ${ }^{4}$ Institute of Cytology and Genetics SB RAS, Novosibirsk, Russia
}

D.S. Ushakov ${ }^{1,2} \otimes$, T.S. Kalinina ${ }^{1,3}$, A.S. Dorozhkova ${ }^{1}$, V.Y. Ovchinnikov ${ }^{4}$, L.F. Gulyaeva ${ }^{1,2,3}$

\begin{abstract}
Many xenobiotics in the human environment, such as benzo[a]pyrene $(\mathrm{B}(\mathrm{a}) \mathrm{P})$ and dichlorodiphenyltrichloroethane (DDT), may act as non-genotoxic carcinogens through epigenetic mechanisms, including changes in microRNA expression profile. In part, such disorders can be mediated by the activation of nuclear receptors, resulting in the activation of protein coding gene expression and microRNAs involved in malignant transformation of cells. Therefore, the aim of this study was to investigate the chain of events "xenobiotic administration receptor activation - up-regulating microRNA expression down-regulation target genes expression" as one of the key factors in the chemically-induced carcinogenesis. Using in silico methods, an analysis of the rat genome was carried out to find microRNAs putatively regulated by AhR (aryl hydrocarbon receptor) and CAR (constitutive androstane receptor), activated by BP and DDT, respectively. In particular, miR-3577 and $-193 \mathrm{~b}$ were selected as potentially regulated CAR, miR-207 was selected as a candidate for miR under AhR regulation. The results of the study showed that the treatment of female rats with DDT and B(a)P caused a tissue-specific changes in the expression of microRNAs and host genes in both acute and chronic administration of xenobiotics. To confirm the effects of xenobiotics on the microRNA expression, we also estimated the mRNA level of PTPN6, EIF3F, Cbx7, and Dicer1 genes potentially targeting miR-193b, -207, and -3577 . The study has shown a high correlation between the expression of target genes and microRNAs; however these changes depended on the tissue types, the dose and time after xenobiotic treatment.
\end{abstract}

Key words: microRNA; target-genes; host-genes; qPCR-RT; bioinformatics; in silico; molecular biology; RNA interference.

HOW TO CITE THIS ARTICLE:

Ushakov D.S., Kalinina T.S., Dorozhkova A.S., Ovchinnikov V.Y., Gulyaeva L.F. Tissue-specific effects of benzo[a]pyrene and DDT on microRNA expression profile in female rats. Vavilovskii Zhurnal Genetiki i Selektsii = Vavilov Journal of Genetics and Breeding. 2018;22(2):248-255. DOI 10.18699/VJ18.355

\section{Тканеспецифичные эффекты бенз[а]пирена и ДДТ на профиль экспрессии микроРНК у самок крыс}

\author{
А.С. Ушаков ${ }^{1,2} \otimes$, Т.С. Каминина ${ }^{1,3}$, А.С. Аорожкова ${ }^{1}$, \\ В.Ю. Овчинников ${ }^{4}, \Lambda . Ф$. Гумяева ${ }^{1,2,3}$ \\ ${ }^{1}$ Научно-исследовательский институт молекулярной биологии \\ и биофизики, Новосибирск, Россия \\ 2 Новосибирский государственный педагогический университет \\ Новосибирск, Россия \\ ${ }^{3}$ Новосибирский национальный исследовательский \\ государственный университет, Новосибирск, Россия \\ ${ }^{4}$ Федеральный исследовательский центр Институт цитологии \\ и генетики Сибирского отделения Российской академии наук, \\ Новосибирск, Россия
}

Многие ксенобиотики окружающей среды, такие как бенз[а]пирен (Б(а)П) и 1,1,1-трихлор-2,2-бис(4-хлорфенил) этан (ДДТ), обладают эпигенетическими механизмами повреждения клеток, приводящими к развитию канцерогенеза. Отчасти эти нарушения могут быть опосредованы активацией ядерных рецепторов, приводящей к активации экспрессии генов и микроРНК, участвующих в процессах злокачественной трансформации клеток. Поэтому целью данной работы было исследовать цепь событий «введение ксенобиотика - активация рецептора - повышение экспрессии микроРНК - понижение экспрессии гена-мишени» в качестве одного из ключевых факторов развития канцерогенеза. С помощью методов in silico проведен анализ генома крыс для поиска микроРНК, находящихся под регуляцией AhR (арил-гидрокарбонового рецептора) и CAR (конститутивного андростанового рецептора), активируемых под действием Б(а)П и ДДТ соответственно. В частности, miR-3577 и -193b были отобраны в качестве потенциально регулируемых CAR; miR-207 - как кандидат на микроРНК, находящийся под регуляцией AhR. Результаты исследования показали, что введение ДДТ и Б(а)П вызывало тканеспецифичное изменение экспрессии микроРНК и их генов-хозяев в случае как острого, так и хронического введений ксенобиотиков. Для подтверждения эффектов ксенобиотиков на экспрессию микроРНК мы также оценили уровень мРНК генов PTPN6, EIF3F, Cbx7 и Dicer1, потенциально являющихся мишенями miR-193b, -207 и -3577. Исследование показало высокую связь экспрессии генов-мишеней и микроРНК, однако точный характер этих изменений зависел от типа ткани, времени после введения и дозы ксенобиотика.

Ключевые слова: микроРНК; гены-мишени; гены-хозяева; ОТ-ПЦР РВ; биоинформатика; in silico; молекулярная биология; РНК-интерференция. 
M icroRNAs (miRs) are short molecules with a length of 18-22 nucleotides, which play an important role in post-transcriptional regulation of gene expression. The mechanism of regulation of expression of protein-coding genes is determined by the degree of complementarity between the miRNAs and target mRNA. One of the mechanisms of such regulation is the RNA interference between the "seed" sequence of microRNA and the $3^{\prime}$-end $\left(5^{\prime}\right.$-end in less rare cases) of the mRNA transcribed from the target gene. In case of complete complementarity, binding of microRNAs to mRNA results in dissection and degradation of the latter, while mRNA translation is suppressed at the initiation or elongation stages, mRNA is destabilized by cleavage of the polyA-tail and sent to the P-body (processing bodies) (Brengues et al., 2005; Yue et al., 2011). A number of recent studies on quantitative and qualitative miRs have shown significant changes in the expression profile for various diseases, including cancer tumors (Hata, Kashira, 2015). Then, profiling the expression of miRs can be a valuable tool for the diagnosis and treatment of many diseases. However, the causes leading to a change in the expression of miRs remain unclear. Understanding molecular mechanisms regulating microRNA expression can explain the differences in the expression of protein-coding genes. Several different mechanisms involved in regulating the expression of microRNA at the transcriptional and post-transcriptional levels are assumed (Gulyaeva et al., 2016).

Transcriptional regulation includes changes in the host gene expression along with a change in intragenic miR or an independent change in miR expression having an intrinsic (intergenic) promoter. In this case, the change in expression can be achieved through signaling cell cascades triggered by various stimuli, including endogenous compounds, such as, for example, hormones and xenobiotics. The post-transcriptional mechanism is based on the changes in processing and stability of microRNAs (Finnegan, Pasquinelli, 2013). A growing body of evidence attests to the key role microRNAs play in chemically induced carcinogenesis. Experimental data demonstrate specific changes in the profile of microRNA expression under the influence of various carcinogens. Therefore, microRNAs can serve as markers of xenobiotic toxicity for early detection of cancer. For example, it has been demonstrated that the expression of 5 microRNAs (miR-29b, miR-31, miR-101a, miR-130a and miR-199a-5p) changes both in the treatment of embryonic fibroblasts by 2,3,7,8-tetrachlorodibenzo-p-dioxin (Agent Orange) and under the influence of ionizing radiation (Huumonen et al., 2015). Genomic sequencing methods enabled to observe the changes in the expression of microRNAs, including 5 up-regulated and 5 down-regulated microRNAs in hemopoietic progenitor cells of C57BL/6 mice after 4 weeks of continuous benzol administration (Wei et al., 2015). Expression of some miRs also significantly changed in human hepatocytes incubated with $\mathrm{B}(\mathrm{a}) \mathrm{P}$, after that the transcript was sequenced using RNA libraries and significant changes in miRs expression profiles were revealed (Caiment et al., 2015). The authors proposed a new mechanism of action of this carcinogen, not according to the classical genotoxic scenario, but through epigenetic mechanisms involving miRs. Previous studies conducted by our team also showed that such known oncogenic miRs as miR-21, -221, -222, alter the expression in the liver of rats exposed to phenobarbital and DDT (Gulyaeva,
Kushlinskiy, 2016). In most cases, the precise mechanism of the effect of various exogenous and endogenous chemical compounds on the miR expression remains insufficiently studied. The activation of nuclear receptors, in cases when xenobiotics can be their ligands, with subsequent changes in the expression of target genes can be one of such mechanisms. In their turn, these genes can contain intronic (intragenic miRs), which will be co-expressed with host genes. It is possible that miRs having their own promoter (intergenic miRs) exist in the genome as well. Therefore, the goal of this study to test this assumption was set. The chosen compounds are ligands for nuclear receptors: DDT can activate CAR, while $\mathrm{B}(\mathrm{a}) \mathrm{P}$ can activate AhR. CAR is an orphan nuclear receptor that forms heterodimers with RXRa (retinoic X receptor) leading to nuclear translocation and transactivation of target genes. Activated CAR heterodimers bind to a number of regulatory regions of target genes eliciting transactivation of CYP2B genes (Xing et al., 2012). AhR is a transcription factor that responds to diverse ligands and plays a critical role in toxicology, immune function, and cardiovascular physiology (Harada et al., 2016). With bioinformatic analysis microRNAs whose promoters had promoters of host genes, as well as intergenic miRs were found, and their expression in different organs of female rats treated with these xenobiotics was investigated. The choice of females was due to the fact that DDT also has an estrogen-like effect, so its toxic effect may be more pronounced in females.

\section{Materials and methods}

Bioinformatic analysis of the rat genome. MicroRNA candidates were selected using search algorithms (Targetscan, miRDB, Diana-microT) and miRRase (miRBase, UCSC, NCBI, Ensembl) databases or the microRNAs themselves, with DRE or PBREM sequences in the promoter region (Table 1). For selected miRs, their target genes according to the parameter of minimum free energy of duplexes were analyzed and selected. When choosing the target genes, TargetScan, miRTarget, miRanda, PITA algorithms were used.

Animals. Female Wistar rats weighing $150 \mathrm{~g}$ were taken from the nursery of the Institute of Clinical Immunology (Novosibirsk, Russia). 4 rats were injected DDT and 4 rats were injected with $\mathrm{B}(\mathrm{a}) \mathrm{P}$ once intraperitoneally, in doses of $50 \mathrm{mg} / \mathrm{kg}$ and $75 \mathrm{mg} / \mathrm{kg}$, respectively, in a solution of $0.5 \mathrm{ml}$ of vegetable oil. The control group $(n=4)$ received $0.5 \mathrm{ml}$ of oil intraperitoneally. Animals were killed by decapitation 72 hours after the injection. Also, 16 rats were intraperitoneally injected with DDT and B(a)P in doses of $10 \mathrm{mg} / \mathrm{kg}$ (low-dose group, $n=4$ ) and $50 \mathrm{mg} / \mathrm{kg}$ (high-dose group, $n=4$ ) weekly. The control group $(n=8)$ received $0.5 \mathrm{ml}$ of oil intraperitoneally weekly. Animals were killed by decapitation 13 weeks after the introduction of xenobiotics began. Animals were kept in natural light and with free access to water and food. All experimental procedures were approved by the Bioethics Committee of the Institute of Molecular Biology and Biophysics.

Isolation of microsomal fraction from liver. Rat liver was perfused with a solution containing $10 \mathrm{mM}$ Tris- $\mathrm{HCl}(\mathrm{pH}$ 7.4) and $1.15 \% \mathrm{KCl}$. A microsomal fraction was isolated at $4{ }^{\circ} \mathrm{C}$ according to a standard procedure; differential centrifugation of tissue homogenates was carried out in a medium containing $10 \mathrm{mM}$ Tris- $\mathrm{HCl}(\mathrm{pH} 7.4)$ and $1.15 \% \mathrm{KCl}$ at $15,000 \mathrm{~g}$ for $15 \mathrm{~min}$. The concentrations of microsomal proteins were 
Table 1. A list of miRs, their host genes and target genes selected using in silico analysis

\begin{tabular}{|c|c|c|c|}
\hline Responsive element in the promoter & Host-gene & MicroRNA & Target gene \\
\hline DRE & DnaJ & miR-207 & PTPN6, EIF3F \\
\hline \multirow[t]{2}{*}{ PBREM } & Intergenic & miR-193b & ERa, Cyclin D1 \\
\hline & Tmem94 & miR-3577 & Cbx7, Dicer1 \\
\hline
\end{tabular}

Table 2. Nucleotide sequences of stem-loop primers in studied microRNAs and comparison genes

\begin{tabular}{ll}
\hline Gene & Stem-loop primer sequence \\
\hdashline U6 & 5'-GTCGTATCCAGTGCAGGGTCCGAGGTATTCGCACTGGATACGACGGCCATGC-3' $^{\prime}$ \\
\hline U48 & 5'-GTCGTATCCAGTGCAGGGTCCGAGGTATTCGCACTGGATACGAGACGGTCAG-3' $^{\prime}$ \\
\hline miR-207 & 5'-GTCGTATCCAGTGCAGGGTCCGAGGTATTCGCATGGATCGATTAATATATGGCT-3' $^{\prime}$ \\
\hline miR-193b & 5'-GTCGTATCCAGTGCAGGGTCCGAGGTATTCGCACTGGATACGACTCTCGCCC-3' $^{\prime}$ \\
\hline miR-3577 & 5'-GTCGTATCCAGTGCAGGGTCCGAGGTATTCGCACTGGATACGACCTAAGGGC-3' $^{\prime}$
\end{tabular}

Table 3. Nucleotide sequences of forward, reverse primers and cDNA probe of the microRNAs under study and reference genes

\begin{tabular}{|c|c|c|}
\hline Gene & Primer type & Sequence \\
\hline \multirow[t]{3}{*}{ U6 } & Forward & 5'-GCCGCATACAGAGAAGATTA-3' \\
\hline & Reverse & 5'-AGTGCAGGGTCCGAGGTA-3' \\
\hline & Probe & 5'-(R6G)-TTCGCACTGGATACGACGGCCATGC-(BHQ1)-3' \\
\hline \multirow[t]{3}{*}{ U48 } & Forward & 5'-CCATGAGTGTCTTCGCTGACG-3' \\
\hline & Reverse & 5'-AGTGCAGGGTCCGAGGTA-3' \\
\hline & Probe & 5'-(R6G)-TTCGCACTGGATACGACGGCCATGC-(BHQ1)-3' \\
\hline \multirow[t]{3}{*}{ miR-207 } & Forward & 5'-GCCGCCTTCTCCGAGGTA-3' \\
\hline & Reverse & 5'-AGTGCAGGGTCCGAGGTA-3' \\
\hline & Probe & 5'-(R6G)-TTCGCACTGGATACGAGAAAGGGAG-(BHQ1)-3' \\
\hline \multirow[t]{3}{*}{ miR-193b } & Forward & 5'-GCCGCGGGGTTTTGA-3' \\
\hline & Reverse & 5'-AGTGCAGGGTCCGAGGTA-3' \\
\hline & Probe & 5'-(R6G)-TTCGCACTGGATACGACTCTCGCCC-(BHQ1)-3' \\
\hline \multirow[t]{3}{*}{ miR-3577 } & Forward & 5'-GCCGCTCTGTCCCTCTTG-3' \\
\hline & Reverse & 5'-AGTGCAGGGTCCGAGGTA-3' \\
\hline & Probe & 5'-(R6G)-TTCGCACTGGATACGACCTAAGGGC-(BHQ1)-3' \\
\hline
\end{tabular}

determined using the Bradford method. Protein samples were diluted with water and added to $1 \mathrm{ml}$ of Bradford's reagent (Fermentas ${ }^{\circledR}$, Lithuania). Samples were incubated for 5 minutes at room temperature, and then the optical density of the solution was measured using an Agilent-8453 spectrophotometer at a wavelength of $595 \mathrm{~nm}$ against a control solution (water with reagent).

Determination of CYP activity. The enzymatic activity of cytochromes $\mathrm{P} 450$ was measured by the rate of O-dealkylation of 7-ethoxy-, 7-methoxy- and 7-pentoxy-resorufin (highly specific substrates for CYP1A1, CYP1A2 and CYP2B, respectively). The formation of the reaction product (resorufin) was determined kinetically using the fluorometric spectroscopy method $\left(\lambda_{\mathrm{ex}}=530, \lambda_{\mathrm{em}}=585\right)$. Twenty milligrams of microsomal protein were added to $0.4 \mathrm{ml}$ of the buffer $(50 \mathrm{mM}$ HEPES, $15 \mathrm{mM} \mathrm{MgCl}_{2}, 0.1 \mathrm{mM}$ EDTA, $\mathrm{pH}$ 7.6) containing the substrate $(1 \mu \mathrm{g})$ and NADPH $(1 \mathrm{mM})$; the reaction was carried out with a large excess of substrate. One minute after the start of the reaction, the dependence of resorufin concentration on time became linear. The activity was measured in accordance with the total protein content. Resorufin was used as a standard for the calibration curve.

Isolation of total RNA for the determination of microRNA expression. Total RNA was isolated as described previously (Chanyshev et al., 2017). $500 \mu \mathrm{l}$ of guanidine lysis buffer (4 M guanidine isothiocyanate, $25 \mathrm{mM}$ sodium citrate, $0.3 \%$ sarcosyl, $0.1 \%$ 2-mercaptoethanol and $0.1 \mathrm{M}$ sodium acetate) was added to $50 \mathrm{mg}$ of tissue. The solution was mixed and incubated at $65{ }^{\circ} \mathrm{C}$ for 10 minutes. Samples were centrifuged at $10,000 \mathrm{~g}$ for 2 minutes, the supernatant was added to the equivalent volume of isopropanol, mixed, incubated at room temperature for 5 minutes, and centrifuged at $10,000 \mathrm{~g}$ for 2 minutes. Total RNA and mRNA samples were stored at $-70{ }^{\circ} \mathrm{C}$. 
The reaction of reverse transcription. To obtain cDNA from the sample microRNA, a reverse transcription reaction was used with the following stem-loop primers with a set for reverse transcription (Biolabmix, Novosibirsk) according to the manufacturer's recommendations. The primers that were used are shown in Table 2.

Quantitative real time polymerase chain reaction (qRTPCR). The relative microRNA expression level under study was determined by stem-loop RT subsequent real-time PCR using TaqMan technology and the PCR kit (Biolabmix, Novosibirsk) according to the manufacturer's recommendations on the CFX96 ${ }^{\mathrm{TM}}$ Real-Time PCR Detection System (Bio-Rad Laboratories). Small nuclear RNAs U6 and U48 were used as reference genes. The reaction was carried out under the following conditions: initiation denaturation at $94^{\circ} \mathrm{C}$ for $2 \mathrm{~min}$, 40 cycles; denaturation at $94{ }^{\circ} \mathrm{C} 0 \mathrm{~s}$; annealing and elongation at $60{ }^{\circ} \mathrm{C}$ for $20 \mathrm{~s}$. The relative level of expression was calculated using the ddCt method. Below the primers used in the study are shown in Table 3.

RNA isolation for the determination of mRNA expression. RNA was extracted from tissues using the TRIzol Reagent ${ }^{\circledR}$ kit (Ambion, USA) as recommended by the manufacturer. A qualitative evaluation of isolated RNA was performed by electrophoresis in a $1.5 \%$ agarose gel containing ethidium bromide $(5 \mu \mathrm{l}$ per $100 \mathrm{ml})$ for RNA staining in UV. As a buffer for the gel, $1 \times$ TBE $(0.05 \mathrm{M}$ Tris- $\mathrm{HCl}(\mathrm{pH} 8.0)$, $1 \mathrm{mM}$ EDTA, $0.05 \mathrm{M} \mathrm{H}_{3} \mathrm{BO}_{3}$ ) was used. Visual control of the electrophoresis was performed using the VersaDoc Model 4000 (Bio-Rad Laboratories, USA). The quantification of the isolated RNA was determined spectrophotometrically using a Nanophotometer P 360 spectrophotometer (Implen, Germany).

Reverse transcription reaction. Reverse transcription to obtain cDNA was performed from a sample of RNA using a reverse transcription kit (Biolabmix, Russia) according to the manufacturer's recommendations.

RT-PCR in real time. The relative expression levels of host and target genes were determined by RT-PCR using reagents for PCR (Biolabmix, Russia) and the CFX96 ${ }^{\mathrm{TM}}$ Real-Time PCR Detection System (Bio-Rad Laboratories). The housekeeping genes GAPDH, POL $2 A$ and $18 S$ were used as reference genes. The primers used are shown in Table 4.

The PCR conditions were as follows: initiation denaturation at $95^{\circ} \mathrm{C}$ for $3 \mathrm{~min}, 40$ cycles; denaturation at $95^{\circ} \mathrm{C}$ for $15 \mathrm{~s}$; annealing at $58{ }^{\circ} \mathrm{C}$ for $20 \mathrm{~s}$; elongation and removal of fluorescence data at $72{ }^{\circ} \mathrm{C}$ for $30 \mathrm{~s}$. The specificity of PCR was checked by melting curves. The relative level of gene expression was calculated using the ddCt method.

Statistical analysis. The data is given as $\pm \mathrm{SD}$ of three independent experiments. A comparison of the two groups was carried out according to Student's $t$-test, $p<0.05$ was considered statistically significant.

\section{Results}

\section{CYP activity in the liver, as an indicator} of the effects of B(a)P and DDT

Many toxic compounds activate specific nuclear receptors and their target genes, primarily the proteins of the cytochrome P450 superfamily (CYP), which are direct indicators
Table 4. Nucleotide sequences of forward and reverse primers of housekeeping genes, host genes and target genes

\begin{tabular}{|c|c|c|}
\hline Gene & Primer type & Sequence \\
\hline \multirow[t]{2}{*}{ Gapdh } & Forward & 5'-TAAAGGGCATCCTGGGCTACACT-3' \\
\hline & Reverse & 5'-TTACTCCTTGGAGGCCATGTAGG-3' \\
\hline \multirow[t]{2}{*}{ Pol2A } & Forward & 5'-TGTATCCGTACTCACAGC-3' \\
\hline & Reverse & 5'-GTAGAAGAGGCGGGTAAC-3' \\
\hline \multirow[t]{2}{*}{$18 S$} & Forward & 5'-CGGCTACCACATCCAAGGAA-3' \\
\hline & Reverse & 5'-GCTGGAATTACCGCGGCT-3' \\
\hline \multirow[t]{2}{*}{ Tmem94 } & Forward & 5'-GTGCTGCTGCTCTTGTGTTG-3' \\
\hline & Reverse & 5'-TGGTCAATGATGCCCCGAAG-3' \\
\hline \multirow[t]{2}{*}{ DnaJ } & Forward & 5'-CTGTGCTACGCTCCTCTTTCC-3' \\
\hline & Reverse & 5'-GGTTTGACCCCCAGAACATCA-3' \\
\hline \multirow[t]{2}{*}{$E R a$} & Forward & 5'-TGCGCAAGTGTTACGAAGTGG-3' \\
\hline & Reverse & 5'-TTCGGCCTTCCAAGTCATCTC-3' \\
\hline \multirow[t]{2}{*}{ Cyclin D1 } & Forward & 5'-GCCCTCCGTTTCTTACTTC-3' \\
\hline & Reverse & 5'-AGACCTCCTCTTCGCACTTC-3' \\
\hline \multirow[t]{2}{*}{ Cbx7 } & Forward & 5'-ACCAAGCCTCTGAATGTGCT-3' \\
\hline & Reverse & 5'-GCAAGTTCGTTTGTGCTGTGA-3' \\
\hline \multirow[t]{2}{*}{ Dicer1 } & Forward & 5'-GAGTCTCTTGCTGGTGCCAT-3' \\
\hline & Reverse & 5'-CACGGTGACTCTGACCTTCC-3' \\
\hline \multirow[t]{2}{*}{ PTPN6 } & Forward & 5'-GGAAGTGGCCGAAACCGAAA-3' \\
\hline & Reverse & 5'-CCTGGTCATCCACCCTGACTG-3' \\
\hline \multirow[t]{2}{*}{ EIF3F } & Forward & 5'-CTCCGGGCCAGACCTCAA-3' \\
\hline & Reverse & 5'-TCAACAGCCACTTCATCTTCTG-3' \\
\hline
\end{tabular}

of toxic effects. Therefore, in the beginning of our experiment, we determined the activity of CYP1A1/2, the expression of which gene is controlled by AhR activation under the exposure with $\mathrm{B}(\mathrm{a}) \mathrm{P}$, and the CAR-regulated gene $C Y P 2 B$, which is activated by DDT. Both single-dose $(75 \mathrm{mg} / \mathrm{kg})$ and chronic administration of $\mathrm{B}(\mathrm{a}) \mathrm{P}$ to female rats $(10 \mathrm{mg} / \mathrm{kg}$ and $50 \mathrm{mg} / \mathrm{kg}$ ) was accompanied by a significant increase in 7-ethoxyresorufin-O-dealkylase activity in rat liver, indicating activation of AhR-regulated CYP1A (Table 5). On the contrary, a single dose of DDT $(75 \mathrm{mg} / \mathrm{kg})$ and chronic treatment for 3 months in low $(10 \mathrm{mg} / \mathrm{kg})$ and high doses $(50 \mathrm{mg} / \mathrm{kg})$, caused a significant increase in 7-pentoxyresorufin-O-dealkylase activity, which indicates the activation of CAR-regulated cytochrome P450 CYP1B.

Thus, the obtained results confirmed a significant increase in the expression of AhR- and CAR-regulated genes, which indicates activation of these receptors. In the chronic administration of both $\mathrm{B}(\mathrm{a}) \mathrm{P}$ and DDT, the dose-dependent effects of xenobiotics under study on the receptors are observed.

\section{Experimental confirmation of the expression of host microRNA genes containing DRE and PBEM in the promoter in different organs of female rats}

Bioinformatic analysis showed that the promoter of DnaJ and Tmem 94 genes contains DRE and PBEM elements, respec- 
Table 5. O-dealkylation activity of CYPs in liver of rats after single and chronic administration of B(a)P and DDT, normalized to activity indices in the control group

\begin{tabular}{|c|c|c|c|}
\hline Administration type & CYP1A1 & CYP1A2 & CYP2B \\
\hline \multicolumn{4}{|l|}{$\mathrm{B}(\mathrm{a}) \mathrm{P}$} \\
\hline Acute administration, 75 mg/kg & $66.01 \pm 13.28^{*}$ & $9.42 \pm 1.51^{*}$ & $1.64 \pm 0.24$ \\
\hline Chronic administration, 10 mg/kg & $4.57 \pm 0.48^{*}$ & $3.50 \pm 0.45^{*}$ & $2.23 \pm 0.31$ \\
\hline Chronic administration, $50 \mathrm{mg} / \mathrm{kg}$ & $24.21 \pm 3.38^{*}$ & $12.78 \pm 1.32^{*}$ & $4.20 \pm 0.37^{*}$ \\
\hline Acute administration, $50 \mathrm{mg} / \mathrm{kg}$ & $1.50 \pm 0.41$ & $0.92 \pm 0.09$ & $116.95 \pm 5.22^{*}$ \\
\hline Chronic administration, $10 \mathrm{mg} / \mathrm{kg}$ & $1.85 \pm 0.29$ & $1.98 \pm 0.25$ & $25.96 \pm 5.14^{*}$ \\
\hline Chronic administration, 50 mg/kg & $2.23 \pm 0.21^{*}$ & $2.20 \pm 0.39$ & $30.79 \pm 2.79^{*}$ \\
\hline
\end{tabular}

${ }^{*} p<0.05$ compared with the control.

Table 6. Expression of host genes DnaJ and Tmem 94 in the liver, uterus, ovaries and mammary gland of rats, acute and chronically treated by B(a)P and DDT, respectively

\begin{tabular}{|c|c|c|c|c|}
\hline Administration group & Liver & Ovary & Uterus & Mammary gland \\
\hline \multicolumn{5}{|c|}{ DnaJ } \\
\hline Control group & $1 \pm 0.5$ & $1 \pm 0.3$ & $1 \pm 0.2$ & $1 \pm 0.15$ \\
\hline \multicolumn{5}{|l|}{$B(a) P$} \\
\hline Acute administration, $75 \mathrm{mg} / \mathrm{kg}$ & $3.0 \pm 0.8^{*}$ & $1.75 \pm 0.25^{*}$ & $0.95 \pm 0.1$ & $2.25 \pm 0.5^{*}$ \\
\hline Chronic administration, $10 \mathrm{mg} / \mathrm{kg}$ & $1.8 \pm 0.2^{*}$ & $1.2 \pm 0.4$ & $0.35 \pm 0.1^{*}$ & $0.8 \pm 0.03$ \\
\hline Chronic administration, 50 mg/kg & $2.7 \pm 0.3^{*}$ & $1.1 \pm 0.3$ & $0.5 \pm 0.05^{*}$ & $2.1 \pm 0.3^{*}$ \\
\hline \multicolumn{5}{|c|}{ Tmem94 } \\
\hline \multicolumn{5}{|l|}{ DDT } \\
\hline Acute administration, $50 \mathrm{mg} / \mathrm{kg}$ & $1.55 \pm 0.45$ & $1.3 \pm 0.35$ & $1.2 \pm 0.15$ & $0.8 \pm 0.3$ \\
\hline Chronic administration, $10 \mathrm{mg} / \mathrm{kg}$ & $2.1 \pm 0.7$ & $1.1 \pm 0.9$ & $0.4 \pm 0.25$ & $1.2 \pm 0.5$ \\
\hline
\end{tabular}

Data are normalized to the control group. ${ }^{*} p<0.05$ compared with the control.

tively. Therefore, the expression of these genes in liver, uterus, mammary gland and ovaries of female rats under the influence of DDT and B(a)P was studied. The data are given in Table 6.

As can be seen from the obtained results, tissue-dependent expression of AhR- and CAR-regulated genes under study was observed. Since these receptors are expressed mainly in liver, the highest increase in the expression of potential host genes for miR-207 and miR-3577 has been recorded in this organ. Thus, in the uterus, ovaries, mammary gland of rats under acute or chronic exposure to DDT there were no significant changes in the expression of Tmem 94 , the host gene for miR-3577, although in the liver gene expression tended to increase. One-time administration of B(a)P showed a significant increase in the expression of DnaJ gene in the liver, ovaries and mammary gland in 3,1.7 and 2.3 times, respectively.

\section{Measurement of miRs expression}

The expression level of the target genes of those miRs, potentionally regulated with $\mathrm{AhR}$ and CAR nuclear receptors, was determined (Table 7).
Chronic $\mathrm{B}(\mathrm{a}) \mathrm{P}$ administration resulted in a significant increase in the level of miR-207 in the liver of rats receiving both a low and high dose of a carcinogen (1.7 and 2.7 times, respectively) in comparison with control group. The mammary gland showed a 2-fold increase in the expression of miR-207 in rats receiving a high dose of $\mathrm{B}(\mathrm{a}) \mathrm{P}$. In the ovaries, significant changes in the level of expression were not observed, while in the uterus a significant decrease in expression was observed in both experimental groups of animals ( 0.4 and 0.5 times, respectively).

One-time administration of $\mathrm{B}(\mathrm{a}) \mathrm{P}$ to female rats was accompanied by a 4-fold increase in the level of expression of miR-207 in the liver and a 2-fold increase in expression in the mammary gland (see Table 7). In the ovary and uterus, there was no change in the expression of this microRNA.

In the treatment of rats with a single dose of DDT, the expression of miR-193b also decreased 2-fold in the liver and 1.5 -fold in the ovaries. The reason for this decrease remains unknown, it can be associated with the negative expression's regulation of this microRNA, which is intergenic and has its own promoter. In the remaining organs, no significant changes 
Table 7. The expression of miR-207, miR-193b and miR-3577 in the liver, uterus, ovaries and mammary gland of rats, acute and chronically treated by B(a)P and DDT, respectively

\begin{tabular}{|c|c|c|c|c|}
\hline Administration group & Liver & Ovary & Uterus & Mammary gland \\
\hline \multicolumn{5}{|c|}{ miR-207 } \\
\hline \multicolumn{5}{|l|}{$B(a) P$} \\
\hline Acute administration, $75 \mathrm{mg} / \mathrm{kg}$ & $4.1 \pm 1.2^{*}$ & $1.6 \pm 0.6$ & $0.8 \pm 0.2$ & $2.4 \pm 0.4^{*}$ \\
\hline Chronic administration, $10 \mathrm{mg} / \mathrm{kg}$ & $1.75 \pm 0.4$ & $1.25 \pm 0.3$ & $0.3 \pm 0.1^{*}$ & $0.8 \pm 0.25$ \\
\hline Chronic administration, 50 mg/kg & $2.75 \pm 0.3^{*}$ & $1.1 \pm 0.2$ & $0.5 \pm 0.1^{*}$ & $2.1 \pm 0.3^{*}$ \\
\hline \multicolumn{5}{|c|}{ miR-193b } \\
\hline \multicolumn{5}{|l|}{ DDT } \\
\hline Acute administration, $50 \mathrm{mg} / \mathrm{kg}$ & $0.55 \pm 0.05^{*}$ & $0.6 \pm 0.25$ & $0.5 \pm 0.05$ & $1.2 \pm 0.3$ \\
\hline Chronic administration, $10 \mathrm{mg} / \mathrm{kg}$ & $0.6 \pm 0.15$ & $0.75 \pm 0.2$ & $1.8 \pm 0.9$ & $1.2 \pm 0.3$ \\
\hline Chronic administration, $50 \mathrm{mg} / \mathrm{kg}$ & $0.55 \pm 0.1$ & $0.75 \pm 0.1$ & $1.6 \pm 0.7$ & $1.1 \pm 0.2$ \\
\hline \multicolumn{5}{|c|}{$\operatorname{miR}-3577$} \\
\hline \multicolumn{5}{|l|}{ DDT } \\
\hline Acute administration, $50 \mathrm{mg} / \mathrm{kg}$ & $2.4 \pm 0.5^{*}$ & $1.8 \pm 0.25^{*}$ & $1.65 \pm 0.35$ & $1.1 \pm 0.4$ \\
\hline Chronic administration, $10 \mathrm{mg} / \mathrm{kg}$ & $1.6 \pm 0.55$ & $0.75 \pm 0.25$ & $1.6 \pm 0.7$ & $1.2 \pm 0.2$ \\
\hline Chronic administration, $50 \mathrm{mg} / \mathrm{kg}$ & $2.6 \pm 0.4^{*}$ & $0.75 \pm 0.1$ & $1.5 \pm 0.7$ & $1.1 \pm 0.35$ \\
\hline
\end{tabular}

Data are normalized to the control group. ${ }^{*} p<0.05$ compared with the control.

Table 8. Expression of target genes (PTPN6, EIF3F, Cbx7 and Dicer1) in rat organs, in the case changes in miR expression as potential regulators were statistically significant

\begin{tabular}{|c|c|c|c|}
\hline Administration type & Organ & PTPN6 & EIF3F \\
\hline \multicolumn{4}{|l|}{$B(a) P$} \\
\hline \multirow[t]{2}{*}{ Acute administration, 75 mg/kg } & Liver & $0.22 \pm 0.13$ & $0.14 \pm 0.09$ \\
\hline & Mammary gland & $0.35 \pm 0.15^{*}$ & $0.38 \pm 0.15^{*}$ \\
\hline \multirow[t]{3}{*}{ Chronic administration, $10 \mathrm{mg} / \mathrm{kg}$} & Liver & $0.37 \pm 0.15^{*}$ & $0.56 \pm 0.05^{*}$ \\
\hline & Uterus & $1.71 \pm 0.42$ & $1.7 \pm 0.33$ \\
\hline & Mammary gland & $0.6 \pm 0.3$ & $0.8 \pm 0.3$ \\
\hline \multirow[t]{4}{*}{ Chronic administration, 50 mg/kg } & Liver & $0.36 \pm 0.17^{*}$ & $0.67 \pm 0.1$ \\
\hline & Uterus & $1.38 \pm 0.4$ & $1.1 \pm 0.35$ \\
\hline & Mammary gland & $0.52 \pm 0.12^{*}$ & $0.41 \pm 0.23^{*}$ \\
\hline & & $C b \times 7$ & Dicer1 \\
\hline \multirow[t]{2}{*}{ Acute administration, 50 mg/kg } & Liver & $0.7 \pm 0.35$ & $0.7 \pm 0.35$ \\
\hline & Ovary & $0.45 \pm 0.2$ & $0.9 \pm 0.3$ \\
\hline Chronic administration, $10 \mathrm{mg} / \mathrm{kg}$ & Liver & $0.8 \pm 0.15$ & $1.0 \pm 0.5$ \\
\hline Chronic administration, $50 \mathrm{mg} / \mathrm{kg}$ & Liver & $0.3 \pm 0.2$ & $0.55 \pm 0.4$ \\
\hline
\end{tabular}

Data are normalized to the control group. ${ }^{*} p<0.05$ compared with the control.

in the expression of miR-193b were detected, which may also be due to low CAR activity in the ovaries, breast and uterus.

Chronic administration of DDT resulted in a significant 2.6-fold increase in the expression level of miR-3577 in the liver of rats treated by high-dose DDT. In the uterus, the expression level of this miR tended to increase. The expression level of miR-3577 was measured in an experiment with a single administration of DDT at a dose of $50 \mathrm{mg} / \mathrm{kg}$. In this case, it increased significantly in the liver (2.4 times) and in the ovaries (1.8 times). In other organs, no significant differences were found, which may be due to low CAR activity.

\section{Expression of target genes for microRNAs}

The expression level of the target genes of those miRs that were changed under xenobiotic exposure was determined (Table 8 ). In the mammary gland and liver, there was a sig- 
nificant decrease in the expression of the miR-207 target genes PTPN6 and EIF $3 F$ in various ways of $\mathrm{B}(\mathrm{a}) \mathrm{P}$ administration. There were no significant changes in the expression of $C b x 7$ and Dicer1, which are putative miR-3577 target genes.

\section{Discussion}

The aim of our study was to investigate the mechanisms of xenobiotics exposure to the level of microRNA expression. As a model of the study, female rats treated with such wellknown xenobiotics as B(a)P and DDT were selected. The choice of such compounds is based on the fact that they can activate AhR and CAR, respectively. Therefore, we observed a change in the expression of AhR-and CAR-regulated genes containing in DRE and PBEM promoters, in comparison with changes in the level of miRNA expression and their target genes in different organs of female rats treated with single or chronic doses of B(a)P and DDT. As follows from the results obtained, the effects of studied chemicals depended on both the dose and the time of exposure. The most pronounced effects were observed in the liver: for example, in the case of a single injection of B(a)P, the expression of the AhR-dependent DnaJ gene doubly increased in comparison with the control group. Chronic B(a)P administration showed a dose-dependent character of elevated gene expression: 1.8 and 2.7 times with respect to control for low- and high-dosage groups respectively. In hormone-dependent organs - ovaries, uterus and mammary gland - the tendency to increase in expression was less pronounced. For example in the uterus, the expression of the DnaJ gene decreased with a chronic B(a)P exposure of 0.35 and 0.5 times with respect to control in the case of low- and high-dosage groups. The Tmem 94 gene did not show significant changes in uterine expression with a single administration of DDT.

It is important to note that the change in the gene expression under study is most pronounced with a single dose exposure, whereas in the chronic variant the expression parameters were lower. It can probably be attributed to the toxic effect. Other studies have also shown that chronic effects of $\mathrm{B}(\mathrm{a}) \mathrm{P}$ or DDT can induce apoptosis (Stolpmann et al., 2012; Marouani et al., 2017). The host genes were also unequally expressed in different rat organs, which may be due to the expression level of the receptors themselves. The maximum expression level was observed in the liver, where, as is known, activity of AhR and CAR is high. Nevertheless, we analyzed the coexpression of host genes-miRNA-target genes in the extrahepatic organs too. According to the obtained data, the miR-207 expression profile was similar in many respects to the expression of the DnaJ host gene. Thus, for example, the maximum increase in miR-207 expression was observed in the liver: 4.1, 1.75 and 2.75 times in case of single and chronic low- and high-dosage groups, respectively, and the effect was statistically significant.

In the uterus, the expression of miR-207 decreased, and in case of chronic administration it was 0.3 and 0.5 times reliably with respect to control. In the ovaries, however, no significant changes were observed, but there was a tendency to increase the expression level. In the mammary glands, however, miR-207 expression significantly increased in 2.4 and 2.1 fold in groups with acute and chronic high-dose $\mathrm{B}(\mathrm{a}) \mathrm{P}$ injection, respectively. It should be noted that miR-207 expression increases with Lewis lung carcinoma (Vaidotas et al., 2016).
There is also evidence of an increase in apoptosis induced by radiation through the interference of miR-207 with the Act3 gene (Tan et al., 2014).

Expression of target genes PTPN6 and EIF3F decreased in organs that showed a significant increase in miR-207. Expression of the PTPN6 gene, which encodes protein tyrosine phosphatase, involved in such cellular processes as differentiation and mitotic cycle significantly decreased in the liver, uterus and mammary gland. It is shown that the loss of the function of this protein leads to JAK3-mediated dysregulation of the STAT3 signaling pathway (Demosthenous et al., 2015). The results also showed a decrease in the expression of the $E I F 3 F$ gene, an important regulator of translation and apoptosis in cancer cells (Shi et al., 2006). Consequently, the chain of events: B(a)P-AhR-host gene DnaJ-miR-207-target genes $P T P N 6$ and EIF3F may underlie the epigenetic mechanism of action of this carcinogen. Expression level of miR-3577 had a tendency to increase; the greatest change was observed in the liver (in 2.4, 1.6 and 2.6 times with respect to control with a single, chronic low- and high-dose administration, respectively). The level of expression of miR-3577 in the ovaries and mammary gland did not change reliably. Other researchers also showed a change in the level of microRNA expression under the influence of B(a)P and DDT. Thus, the expression of microRNA was significantly changed when human hepatocytes were incubated with benzo[a]pyrene.

Using two different RNA libraries, a whole transcriptome of these cells was sequenced and a conclusion was drawn on a new look at the mechanism of action of this carcinogen (Wei et al., 2015). Enhanced expression of miR-410 and miR-122 in human hepatoma HepaRG cells in response to Aflatoxin B1 and benzo[a]pyrene was also shown (Marrone et al., 2016). These facts suggest that changes in microRNA expression profile can reflect the early events of the non-genotoxic mechanism of action of these genotoxic carcinogens. DDT can also affect the expression of miRNA in mammary cells (Tilghman et al., 2012). This study identified microRNA expression profiles in MCF-7 cells by incubation with estradiol, BPA or DDT confirmed estrogen-like effects of EDCs, although there were differences from the natural hormone. It should be noted that a number of theoretical studies have been published earlier that have shown the interrelation of the expression of miRNA, transcription factors, "host genes" and targets for miRNA in various malignant tumors (Ye et al., 2014; Song et al., 2015). Our results have experimentally confirmed this mechanism, although it largely depends on the tissue type, time and dose of exposure to xenobiotics.

\section{Conclusion}

Thus, among a variety of mechanisms regulating the expression of microRNAs, a special place is taken by the mechanisms of activation of receptors-xenosensors, which are able to be activated by xenobiotics-ligands. A large number of toxic compounds are known to be incapable of adduct formation with DNA or proteins (such as DDT or TCDD), they act according to different, epigenetic mechanisms. Moreover, genotoxic compounds, such as PAHs, including B(a)P, can not only form DNA adducts, but also bind to AhR, activating multiple target genes, including microRNAs. The results of our work showed that, in fact, the activation of AhR- and 
CAR-regulated genes under the $\mathrm{B}(\mathrm{a}) \mathrm{P}$ and DDT exposure is accompanied by an increase in the transcription of their target genes, not only CYPs, but also other genes, including Tmem 94 and DnaJ. With these genes, miR-3577 and miR-207 are coexpressed.

\section{Acknowledgments}

The reported study was funded by RFBR according to the research project No. 15-03-01700.

\section{Conflict of interest}

The authors declare no conflict of interest.

\section{References}

Brengues M., Teixeira D., Parker R. Movement of eukaryotic mRNAs between polysomes and cytoplasmic processing bodies. Science. 2005;310(5747):486-489. DOI 10.1126/science.1115791.

Caiment F., Gaj S., Claessen S., Kleinjans J. High-throughput data integration of RNA-miRNA-circRNA reveals novel insights into mechanisms of benzo[a]pyrene-induced carcinogenicity. Nucleic Acids Res. 2015;43:2525-2534. DOI 10.1093/nar/gkv115.

Chanyshev M.D., Ushakov D.S., Gulyaeva L.F. Expression of miR-21 and its Acat1, Armcx 1, and Pten target genes in liver of female rats treated with DDT and benzo[a]pyrene. Mol. Biol. (Mosk). 2017; 51(4):664-670. DOI 10.7868/S0026898417040085.

Demosthenous C., Han J.J., Hu G., Stenson M., Gupta M. Loss of function mutations in PTPN6 promote STAT3 deregulation via JAK3 kinase in diffuse large B-cell lymphoma. Oncotarget. 2015;6(42): 44703-44713. DOI 10.18632/oncotarget.6300.

Finnegan E.F., Pasquinelli A.E. MicroRNA biogenesis: regulating the regulators. Crit. Rev. Biochem. Mol. Biol. 2013;48:51-68. DOI 10.3109/10409238.2012.738643.

Gulyaeva L.F., Chanyshev M.D., Kolmykov S.K., Ushakov D.S., Nechkin S.S. Effect of xenobiotics on microRNA expression in rat liver. Biomed. Khim. 2016;62(2):154-159. DOI 10.18097/PBMC 20166202154.

Gulyaeva L.F., Kushlinskiy N.E. Regulatory mechanisms of microRNA expression. J. Transl. Med. 2016;14(1):143-153. DOI 10.1186/ s12967-016-0893-x.

Harada T., Takeda M., Kojima S., Tomiyama N. Toxicity and carcinogenicity of dichlorodiphenyltrichloroethane (DDT). Toxicol. Res. 2016;32(1):21-33. DOI 10.5487/TR.2016.32.1.021.

Hata A., Kashima R. Dysregulation of microRNA biogenesis machinery in cancer. Crit. Rev. Biochem. Mol. Biol. 2015;1:1-14. DOI 10.3109/10409238.2015.1117054.

Huumonen K., Korkalainen M., Viluksela M., Lahtinen T., Naarala J., Juutilainen J. Role of microRNAs and DNA methyltransferases in transmitting induced genomic instability between cell generations. Front. Public Health. 2015;2(139):1-9. DOI 10.3389/fpubh. 2014.00139
Marouani N., Hallegue D., Sakly M., Benkhalifa M., Ben Rhouma K., Tebourbi O. p,p'-DDT induces testicular oxidative stress-induced apoptosis in adult rats. Reprod. Biol. Endocrinol. 2017;15:40. DOI 10.1186/s12958-017-0259-0.

Marrone A.K., Tryndyak V., Beland F.A., Pogribny I.P. MicroRNA responses to the genotoxic carcinogens aflatoxin $\mathrm{B}_{1}$ and benzo[a] pyrene in human HepaRG cells. Toxicol. Sci. 2016;149(2):496-502. DOI 10.1093/toxsci/kfv253.

Shi J., Kahle A., Hershey J.W., Honchak B.M., Warneke J.A., Leong S.P., Nelson M.A. Decreased expression of eukaryotic initiation factor $3 \mathrm{f}$ deregulates translation and apoptosis in tumor cells. Oncogene. 2006;25(35):4923-4936. Epub 2006 Mar 13. DOI 10.1038/ sj.onc. 1209495.

Song C., Xu Z., Jin Y., Zhu M., Wang K., Wang N. The network of microRNAs, transcription factors, target genes and host genes in human renal cell carcinoma. Oncol. Lett. 2015;9(1):498-506. DOI 10.3892/ol.2014.2683.

Stolpmann K., Brinkmann J., Salzmann S., Genkinger D., Fritsche E., Hutzler C., Wajant H., Luch A., Henkler F. Activation of the aryl hydrocarbon receptor sensitises human keratinocytes for CD95Land TRAIL-induced apoptosis. Cell Death Dis. 2012;3(9):e388. DOI 10.1038/cddis.2012.127.

Tan P.X., Du S.S., Ren C., Yao Q.W., Zheng R., Li R., Yuan Y.W. MicroRNA-207 enhances radiation-induced apoptosis by directly targeting Akt3 in cochlea hair cells. Cell Death Dis. 2014;5:e1433. DOI 10.1038/cddis.2014.407.

Tilghman S.L., Bratton M.R., Segar H.C., Martin E.C., Rhodes L.V., Li M., McLachlan J.A., Wiese T.E., Nephew K.P., Burow M.E. Endocrine disruptor regulation of microRNA expression in breast carcinoma cells. PLoS One. 2012;7:e32754. DOI 10.1371/journal. pone.0032754.

Vaidotas S., Gintautas V., Danute B., Kestutis S. Gene and miRNA expression signature of Lewis lung carcinoma LLC1 cells in extracellular matrix enriched microenvironment. BMC Cancer. 2016;16:789. DOI 10.1186/s12885-016-2825-9.

Wei H., Zhang J., Tan K., Sun R., Yin L., Pu Y. Benzene-induced aberrant miRNA expression profile in hematopoietic progenitor cells in C57BL/6 mice. Int. J. Mol. Sci. 2015;16:27058-27071. DOI 10.3390/ijms 161126001 .

Xing Y., Nukaya M., Satyshur K.A., Jiang L., Stanevich V., Korkmaz E.N., Burdette L., Kennedy G.D., Cui Q., Bradfield C.A. Identification of the Ah-receptor structural determinants for ligand preferences. Toxicol. Sci. 2012;129(1):86-97. DOI 10.1093/toxsci/ kfs 194.

Ye S., Yang L., Zhao X., Song W., Wang W., Zheng S. Bioinformatics method to predict two regulation mechanism: TF-miRNA-mRNA and IncRNA-miRNA-mRNA in pancreatic cancer. Cell Biochem. Biophys. 2014;70:1849-1858. DOI 10.1007/s12013-014-0142-y.

Yue S.B., Trujillo R.D., Tang Y., O’Gorman W.E., Chen C.Z. Loop nucleotides control primary and mature miRNA function in target recognition and repression. RNA Biol. 2011;8(6):1115-1123. DOI 10.4161/rna.8.6.17626. 